form filling with better clinical information coming from nurses than from their medical colleagues.

Secretary, Endoscopy Committee of the BSG Princess Margaret Hospital, Okus Road, Swindon SN1 4 FU

\section{Measurement of morphokinetic status in experiments on intestinal adaptation}

EDITOR,-The protracted debate concerning appropriate measurements of morphokinetic status in experiments on intestinal adaptation, seems to have passed Reilly et al (Gut 1995; 37: 81-6). There are several points of major concern in their paper.

(1) 'Crypt cell proliferation rate (is determined) by bromodeoxyuridine incorporation'. How? The references quoted are to BrdU in different systems and cannot be used to assess the methodology of Reilly et al. The measurement, called 'crypt cell proliferation (\%)', is not one we recognise: could it be the percentage of BrdU labelled cells? But then, percentage of what? It is surely no longer acceptable in such studies to be allowed to give such measurements without giving readers an indication of the target interphase nuclear population and counting statistics; of course, BrdU does not measure 'crypt cell proliferation', but only one indirect component of it - the $S$ phase fraction. The changes in crypt depth (Table II) show that the several groups have different sized crypt populations: therefore the putative increases in labelling index in SCFA/control, saline/gastrin receptor blockade, and SCFA/gastrin receptor blockade may in fact be modified because of changes in the interphase nuclear population. Such problems are simply avoided by using the whole crypt as a denominator, as is now widely used. ${ }^{1}$

(2) The fact that both groups receiving the gastrin blocker (saline/gastrin receptor blockade and SCFA/gastrin receptor blockade) show a significant increase in labelling index compared with saline control, and that the SCFA/gastrin receptor blockade group is significantly larger than the SCFA control receives no mention in the discussion; these differences are also reflected in the crypt depth and villous height measurements (Table II). What is going on here: does the gastric receptor antagonist itself stimulate cell proliferation?

Some light may be cast on this by the weight data: both gastrin receptor blockade groups gained significantly more weight than the control group. Food intake in the various groups is an important modulator of intestinal proliferation and was evidently not monitored: it is certainly not mentioned. Consequently, a possible interpretation is that gastrin receptor blockade increases food intake and hence intestinal cell proliferation: the addition of SCFA in this model fails to further increase cell proliferation. And to argue that other measures such as DNA and protein, support the interpretation is neither here nor there: it is difficult to support such measurements for critical work. ${ }^{2}$ What is meant by 'jejunum'? Clarke pointed out many years ago that rats do not have jejunums and ileums, so what does jejunal weight mean? We assume that 'crypt death' measurements were a figment of inadequate proof reading.

It is difficult, if not impossible, to make any conclusions from this study: it will no doubt have to be repeated, monitoring food intake or feeding rats parenterally, with more critical measurements. Histopathology 35-43 Lincoln's Inn Fields, London WC2A 3PN

1 Goodlad RA. Microdissection-based techniques for the determination of cell proliferation in gastrointestinal epithelium: application to animal and human studies. In: Celis JE. Cell biology: $a$ laboratory handbook. San Diego: Academic laboratory hand

2 Wright NA, Alison MR. The biology of epithelial cell populations. Vol 2. Oxford: Oxford University Press, 1984.

\section{Reply}

EDITOR,-George Bernard Shaw once said 'England and America are two countries divided by a common language'. ${ }^{1}$ The letter by Wright and Goodlad personifies this divisiveness. Citing their own studies of the crypt cell production rate (CCPR) as the purported 'gold standard' for measurement of intestinal proliferation, Wright and Goodlad question our measure with bromodeoxyuridine (BrdU) and wonder why we did not use their technique. Interestingly, we are not the first 'nonconformists' to incur the vent of their partisan wrath, as expressed in another vituperative letter by Goodlad 'Defective denominators or will people never learn?' (Gastroenterology $1995 ; 108: 1963)$. On this side of the pond, experienced investigators use tritiated-thymidine incorporation to quantify ' $S$ ' phase cells, proliferating cell nuclear antigen (PCNA), and BrdU to measure proliferating cells, or enzyme markers such as thymidine kinase or ornithine decarboxylase as indicators of cell proliferation. Flow cytometry is also used in combination with some of the staining techniques. We believe all of these methods are valid comparisons within a single experiment. There is clearly not a general agreement on a 'gold standard' for this measure. BrdU immunohistochemistry, performed in our study, is used by many to yield semi-quantitative information that directly correlates with cell proliferation in many in vitro and in vivo experimental systems. The accuracy of BrdU labelling indices to study in vivo proliferation in the digestive tract in rats has been clearly shown. ${ }^{2}$

We agree that BrdU immunohistochemistry is an imperfect measure of crypt cell proliferation because (similar to tritiated-thymidine) it only measures the number of cells cycling through the ' $S$ ' phase of the cell cycle. Readers of Gut and most gastrointestinal scientists are well aware of this characteristic. The reality remains that although imperfect, BrdU labelling indices (as well as labelling indices obtained by tritiated-thymidine or PCNA) are to date widely accepted as accurate and reliable indices of intestinal proliferation, which can be used for internal comparisons within a single experiment.

It is well accepted that labelling indices can be expressed as the number of labelled cells, divided by the total cells (labelled plus unlabelled) in the entire crypt. Many investigators multiply this ratio by 100 , such as performed in our study, to express the index as a percentage value rather than a fraction. ${ }^{3-8}$ One of the references included in our paper clearly explains this simple calculation ${ }^{3}$ (Table I, page 700), information seemingly overlooked by Wright and Goodlad. Perhaps the confusion stems, in part, from the unintended omission of the number of crypts counted per rat. As indicated in our report for the measurements of villous height and crypt depth, 20 well oriented crypts per animal were randomly selected for assessment of BrdU labelled and unlabelled cells. Labelling index was then calculated by counting the number of BrdU labelled cells and expressing the results as percentage of the total cells (labelled plus unlabelled) counted in the crypts assayed in each rat.

Many scientists ${ }^{4-8}$ choose to study intestinal proliferation by BrdU incorporation assessed and expressed as labelling index percentage such as described in our study. This sample of references is woefully incomplete but serves to strengthen our point. These publications include in vitro and in vivo studies all of which use BrdU labelling indices as a measure of intestinal proliferation in the same manner as reported in our paper. While Wright and Goodlad continue to express their bias for the CCPR technique, a search of Current Contents Article Records using the key words 'proliferation' and 'intestine' yielded 89 publications in 1995, only two of which reported use of the CCPR. While the majority may not rule in science, it is clear that the majority have not embraced CCPR.

Wright and Goodlad correctly state that 'food intake is an important modulator of intestinal proliferation.' We agree that controlled dietary intake, such as provided by total parental nutrition, gastrostomy feeding, or pair feeding is important in nutritionally oriented studies. Moreover, we have used these methods extensively in other investigations. ${ }^{9-10}$ These methods were not used in this study based upon pilot data (unpublished) showing no significant differences in dietary intake between the gastrin receptor blocker and control groups. Despite the results of our unpublished pilot investigations, the gastrin receptor blockade groups collectively gained more weight than the control groups in the published study. There was no observed increase in dietary intake in the gastrin receptor blockade groups, however, actual food intake was not measured and it may have been increased in the gastrin receptor blockade groups. Nevertheless, we intend to repeat these studies with controlled dietary intake.

Wright and Goodlad quibble about our use of the terms 'jejunum' and 'ileum' to describe the anatomy of the small intestine in the rat. We would like to point out that they have extensively and correctly used the terms jejunum and ileum in many of their previous publications. ${ }^{11-14}$ Thus a review of their own work, in addition to a standard textbook on the anatomy of the laboratory rat $^{15}$ is strongly recommended.

In summary, an objective review of the literature clearly shows that there are widespread fundamental differences as to whether there is a single best measurement of cell proliferation and what that measure should be. The weight gain in our gastrin receptor blockade groups may have influenced some of the morphometric measures, and further studies with controlled dietary intake are planned. Wright and Goodlad's comments that 'rats do not have jejunums and ileums' is incorrect. To return to Shaw, No man fully capable of his own language ever masters another'.16

K J REILLY

W L FRANKEL A M BAIN J L ROMBEAU

Hospital of the University of Pennsylvania, 3400, Spruce Street, Philadelphia PA 19104, USA 
1 Oxford Dictionary of Quotations. 4th Ed. Oxford: 1992: 638.

2 Lacy ER, Kuwayama H, Cowart KS, King JS, Deutz AH, Sistrunk S. A rapid, accurate, immunohistochemical method to label proliferating cells in the digestive tract: a comparison ating cells in the digestive tract: a comparison 100: 259-62.

3 Morstyn G, Pyke K, Gardner J, Ashcroft R, Fazio Ad, Bhathal P. Immunohistochemical identification of proliferating cells in organ culture using bromodeoxyuridine and a monoclonal antibody. f Histochem Cytochem 1986; 4: 697-701.

4 Cahill RJ, O'Sullivan KR, Mathias PM, Beattie $S$, Hamilton H, O'Morain C. Effects of vitamin antioxydant supplementation on cell kinetics of patients with adenomatous polyps. Gut 1993; 34: 963-7.

5 Sobhani IJ, Lhy T, Laurent-Puig P, Cadiot G, Ruszniewski P, Mignon M. Chronic endogenous hypergastrinemia in humans: evidence for a mitogenic effect on the colonic mucosa. Gastroentrology 1993; 105: 22-30.

6 Bartram HP, Gostner A, Scheppach W, Reddy BS, Rao CV, Dusel G, et al. Effects of fish oil on rectal cell proliferation, mucosal fatty acids, and prostaglandin $E_{2}$ release in healthy subjects. Gastroenterology 1993; 105: 1317-22.

7 Potten CS, Kellett M, Roberts SA, Rew DA, Wilson GD. Measurement of in vivo proliferation in human colorectal mucosa using bromodeoxyuridine. Gut 1992; 33: 71-8.

8 Scheppach W, Loges C, Bartram P, Christl SU, Richter F, Dusel G, et al. Effect of free glutamine and alanyl-glutamine dipeptide on mucosal proliferation of the human ileum and colon. Gastroenterology 1994; 107: 429-34.

9 Mantell MP, Ziegler TR, Adamson WT, Roth JA, Zhang W, Frankel W, et al. ResectionJA, Zhang W, Frankel W, et al. Resection-
induced colonic adaptation is augmented by induced colonic adaptation is augmented by colonic IGF-I mRNA. Am F Physiol 1995; 269: G974-80.

10 Zhang W, Frankel WL, Adamson WT, Roth JA, Mantell MP, Bain A, et al. Insulin-like growth factor-I improves mucosal structure and function is transplanted rat small intestine. Transplantation 1995; 59: 755-61.

11 Savage AP, Gornacz GE, Adrian TE, Ghatei MA, Goodlad RA, Wright NA, et al. Is raised plasma peptide $Y Y$ after intestinal resection in the rat responsible for the trophic response? Gut 1985; 26: 1353-8.

12 Goodlad RA, Plumb JA, Wright NA. Simultaneous measurement of intestinal crypt cell production rate and water absorption. Gut 1987; 28 (suppl 1): 189-92.

13 Goodlad RA, Plumb JA, Wright NA. The relationship between intestinal crypt cell production and intestinal water absorption measured in vitro in the rat. Clin Sci 1987; 72: 297-304.

14 Goodlad RA, Savage AP, Lenton W, Ghatei MA, Gregory H, Bloom SR, et al. Does resection enhance the response of the intestine to urogastrone-epidermal growth factor in the rat? urogastrone-epidermal grow

15 Hebel R, Stromberg MW. Anatomy and embryology of the laboratory rat. Worthsee: Biomed Verlag, 1986.

16 Shaw GB. Maxims for Revolutionists. Quoted in Best Quotations. Henry L ed. New York: Doubleday, 1964

\section{Experimental colitis is ameliorated by} inhibition of nitric oxide synthase activity

EDITOR,-We congratulate Rachmilewitz and colleagues for their paper discussing the effects of nitric oxide synthase inhibition on experimental intestinal inflammation (Gut 1995; 37: 247-55). Using a rat model of colitis induced by $30 \mathrm{mg}$ trinitrobenzenesulphonic acid in 0.5 ml 50\% ethanol (TNBS/E) we have similarly shown the importance of the L-arginine-nitric oxide pathway on mucosal inflammation. ${ }^{1}$ L-arginine given by mouth, the biosynthetic precursor of nitric oxide, promoted the inflammatory response in experimental colitis. Addition of $\mathrm{N}^{\mathrm{G}}$-nitro-L-arginine methyl ester (L-NAME) to the arginine supplemented diet reduced both colonic inflammation and weight loss. In accordance with Rachmilewitz and colleagues, we have also found that oral administration of L-NAME alone, as an oral solution $(500 \mathrm{mg} / \mathrm{l})$ or as an enema, (1 $\mathrm{g} / \mathrm{l}$ ) reduced colonic inflammation in this model of colitis.

Bacteria, bacterial products, and cytokines may all promote induction of calcium independent nitric oxide synthesis in the colonic mucosa. There is evidence that enteric bacteria and their products can penetrate the gut mucosal barrier in patients with inflammatory bowel disease (IBD) and in experimental models of colitis. ${ }^{2} 3$ Increased faecal concentrations of tumour necrosis factor have also been shown in both IBD and TNBS/E induced colitis. ${ }^{45}$ In addition we have recently shown that administration of an antitumour necrosis factor antibody reduces the inflammatory response in this model of colitis. $^{6}$ It is therefore possible that these bacterial products and cytokines may exert a pro-inflammatory action in patients with IBD by the induction of nitric oxide synthesis.

We agree with the authors that modulation of nitric oxide synthase activity may have therapeutic potential in IBD. As shown by Rachmilewitz and colleagues L-NAME given by mouth has potent hypertensive effects, which may limit its usefulness in the treatment of patients with chronic IBD. Topical administration, however, may confer beneficial anti-inflammatory effects with reduced cardiovascular complications.

P J D NEILLY K R GARDINER B J ROWLANDS Department of Surgery, The Queen's University of Belfast,
Grosvenor Road, Belfast BT12 6Bf

1 Neilly PJD, Kirk SJ, Gardiner KR, Anderson NH, Rowlands BJ. Manipulation of the L-argininenitric oxide pathway in experimental colitis. $B$ f Surg 1995; 82: 1188-91.

2 Gardiner KR, Halliday MI, Barclay GR, Milne L Brown D, Stephens S, et al. Significance of systemic endotoxaemia in inflammatory bowel disease. Gut 1995; 36: 897-901.

3 Neilly PJD, Gardiner KR, Kirk SJ, Jennings G Anderson NH, Elia M, et al. Endotoxaemia and cytokine production in experimental inflammatory bow

4 Braegger CP, Nicholls S, Murch SH, Stephens S, MacDonald TT. Tumour necrosis factor alpha in stool as a marker of intestinal inflammation. Lancet 1992; 339: 89-91.

5 Neilly PJD, Campbell GR, Anderson NH Gardiner KR, Kirk SJ, Rowlands BJ. Faeca and systemic tumour necrosis factor in experimental inflammatory bowel disease. Surgical Research Communications 1995; 18: 11-7.

6 Neilly PJD, Gardiner KR, Kirk SJ, Jennings G, Anderson $\mathrm{NH}$, Elia $\mathrm{M}$, Rowlands BJ. AntiAnderson $\mathrm{NH}$, Elia $M$, Rowlands BJ. AntiTNF $\alpha$ antibody reduces the systemic inflam1995; 37 (suppl 2): A16.

\section{Heartburn in patients with achalasia}

EDITOR,-We were interested to read the thought provoking paper on heartburn in patients with achalasia, in which the authors hypothesised that the heartburn described by $48 \%$ of achalasia patients eligible for review was related to gastro-oesophageal reflux disease (GORD) and documented on manometry a relative reduction in basal lower oesophageal sphincter pressure in such patients (Gut 1995; 37: 305-8).

They themselves note that there are many alternative causes for heartburn in patients with achalasia and performed no $\mathrm{pH}$ monitoring to support what they admit remains speculation. However, if such a group of patients did exist and could be reliably selected they would clearly be candidates for an antireflux procedure at the time of treatment by surgical myotomy.
Following an initial study examining the need for an antireflux procedure during laparoscopic Heller's cardiomyotomy, ${ }^{1}$ we have prospectively evaluated patients with achalasia undergoing such surgery with a protocol that includes pre and postoperative 24 hour $\mathrm{pH}$ monitoring.

The 12 patients who have undergone preoperative $\mathrm{pH}$ monitoring had a median composite DeMeester score ${ }^{2}$ of 0.45 (range $0 \cdot 2-16 \cdot 8$ ) (upper limit of normal 14.72 at $\mathrm{pH}$ threshold <4) only one patient showed abnormal oesophageal acidity at this stage. Postoperatively in 10 patients the median score increased to $6 \cdot 00$ (range $0 \cdot 2-19 \cdot 6$ ) with two patients lying outside the normal range, one of whom had probably had an inadequate myotomy.

Preoperatively significant reflux was extremely uncommon and these results do not support the hypothesis that the heartburn experienced by patients with achalasia is due to acid reflux. Even after a myotomy completely dividing the lower oesophageal sphincter very few patients showed significant GORD despite their aperistaltic oesophagus and it seems likely that factors such as the crural fibres of the diaphragm ${ }^{3}$ continue to effectively prevent reflux in most patients. A review of 75 papers reporting 5002 patients with achalasia gave an average incidence of postoperative GORD of $8 \cdot 6 \%{ }^{4}$ It is improbable therefore that large numbers of such patients refluxed significantly before the development of their achalasia as speculated by your authors.

\section{G S M ROBERTSON} P S VEITCH Departments of Surgery A C B WICKS and Gastroenterology Leicester General Hospital NHS Trust,
Gwendolen Road, Leicester LE5 4PW

1 Robertson GSM, Lloyd DM, Wicks ACB, de Caestecker-J, Veitch PS. Laparoscopic Heller's cardiomyotomy without an antireflux procedure. Br f Surg 1995; 82: 957-9.

2 Demeester TR. Prolonged oesophageal pH monitoring. In: Read NW, ed. Gastrointestinal motility: which test? Petersfield: Wrightson Biomedical, 1989: 41-52.

3 Peck N, Callander N, Watson A. Manometric assessment of the effect of the diaphragmatic crural sling in gastro-oesophageal reflux: implications for surgical management. Br $\mathcal{f}$ Surg 1995; 82: 798-801.

4 Andreollo NA, Earlam RJ. Heller's myotomy for achalasia: is an added anti-reflux procedure necessary? [review]. Br f Surg 1987; 74: 765-9.

Atlas of Clinical Hepatology. By N Gitlin, R M Strauss. (Pp 183; illustrated; £,92). Philadelphia: W B Saunders, 1995. ISBN 0-7216-4356-6.

The explosion in information technology has revolutionised the way knowledge is sought and processed, but in a manner that reduces the impact of pictorial images on education. The role of the classic textbook as pivotal to teaching is increasingly challenged by 